\title{
THE EFFECT OF HYPOCHLORITE ON SKIN'S MRNA MARKERS IN CONTACT SAMPLES
}

\author{
Samah F. Ibrahim ${ }^{12}$, Mona M. Ali1', Sarah A. Khater ${ }^{3}$ and Laila A. Rashed ${ }^{4}$ \\ ${ }^{1}$ Forensic medicine and clinical toxicology, Cairo University. ${ }^{2}$ Forensic Medicine and \\ Clinical Toxicology, Princess Nourah bint Abdulrahman University, KSA. ${ }^{3}$ Forensic \\ medicine and clinical toxicology- Misr University for Science and Technology. ${ }^{4}$ Medical \\ biochemistry. Cairo University.
}

\begin{abstract}
Background: the identification of human skin through mRNA-based profiling is useful in forensic investigations. A deliberate attempt to remove biological material, through using a variety of cleaning agents, is a problem faced by forensic scientists. Limited information exists on the effect of Hypochlorite $(\mathrm{HOCl})$; cleaning agent; on human skin mRNA markers. Aim: This study evaluated the sensitivity of specific human genetic skin markers; LCE2D and CCL27 to different $\mathrm{HOCl}$ concentrations by using Real-time qPCR. Method: sixty four middle aged healthy volunteers (32 males and 32 females) were included in the study.Results: $\mathrm{HOCl}$ had a pronounced negative effect. The expression of the studied markers was decreased to the quarter of its normal value when the touch samples were submerged in concentrated $\mathrm{HOCl}$ solution.

Conclusion: sample with reduced RNA expressions might be soaked or adulterated before testing and other tests should be used to help in cellular origin determination

Keywords: forensic investigation, touch samples, mRNA skin markers, LCE2D, CCL27, hypochlorite, Real-time qPCR.

\section{INTRODUCTION}

Hypochlorite (HOCl) bleach is used world wide in homes and health care facilities. It has anti-inflammatory and antimicrobial effects. It is considered as an oxidant in addition, it is interfering with cellular signaling process. Diluted $\mathrm{HOCl}$ solutions are used in cleaning skin surface (Rutalaet al., 1998; Huang et al., 2009).

The outer epithelial layer of human skin is continuously developed and shed to leave epithelial cells as biological evidence. Many methods are used to identify the cellular origin of biological stains (Goray et al., 2010). In forensic casework, epithelial identification methodologies are not well established (Hanson et al., 2012). Forensic laboratories use histological examination, UV-light, Polilight1,

(miRNAs) in identifying and differentiating epithelial stains from other biological stains (Haas et al., 2015).

Late cornified envelope (LCE) gene cluster is one of putative skin-specific markers. (LCE) is part of the epidermal differentiation complex and has three groups (1, 2 and 3). The first two groups are dominant in skin (Ballantyne, 2013; Lindenbergh et al., 2013). Chemokine (C-C motif) ligand 27 (CCL27 gene) is found in keratinocytes and has a role in skin inflammation (Jackson et al., 2005). LCE2D and CCL27 can positively identify the epithelial origin of biological stains.

Cleaning agents could be used to destruct the biological stains and degrade its DNA and RNA (Schwark et al., 2012; Visser et al., 2011).
\end{abstract} messenger RNA (mRNA), microRNAs 
AIM OF THE STUDY

This study aimed to demonstrate the effect of different $\mathrm{HOCl}$ concentrations on mRNA expression; LCE2D and CCL27; in touch DNA samples. This effect can determine the value of using mRNA markers in identifying epithelial origin of biological stains.

\section{METHODOLOGY}

After signing an informed consent, sixty four middle aged healthy volunteers (32 males and 32 females) at the biochemistry department, faculty of medicine, Cairo University, were included in the study for one month duration. Every participant touched a slide with right index and middle fingers with 1 minute contact time.

I- Washing solutions, collection and preservation of samples:

To evaluate the effect of $\mathrm{HOCl}$ on the expression of skin RNA markers, the touch samples were merely submerged for 30 seconds with different concentrations of $\mathrm{HOCl}$ solution. These solutions were:

- Full concentrated $\mathrm{HOCl}$ solution: (5.25\% Sodium hypochlorite, EPA Reg. No. 5813-1, Oakland, California) was used as to prepare full concentrated solution according to manufacturer's instructions.

- Half concentrated $\mathrm{HOCl}$ solution was prepared from the previous one. temperature

- Distilled water at room

Slides were divided into 4 groups; group (1) (control) was kept without washing, group (2) was submerged in distilled water, group (3) was submerged in half concentrated $\mathrm{HOCl}$ solution and group (4) was submerged in full concentrated $\mathrm{HOCl}$ solution. Slides were kept in a dry dark place (cartoon box) at room temperature $24^{\circ} \mathrm{C}$ for 2 hours. Therefore, the effect of light and humidity were minimized. Sterile dry cotton swabs were used to collect shed cells.

\section{RNA extraction:}

Total RNA was extracted from cells using the RNeasy Mini Kit (Qiagen Inc); with DNase step to remove DNA, following the manufacturer's protocol extracted RNA was quantified by spectrophotometry. The RNA integrity was assessed using agarose gel electrophoresis and ethidium bromide staining.

III. Conversion of RNA into cDNA:

The total RNA $(0.5-2 \mu \mathrm{g})$ was used for cDNA conversion using high capacity cDNA reverse transcription kit (K1621, Fermentas, USA) according to manufacture instruction.

IV. Quantitative real time PCR (qRT-PCR):

Real-time qPCR amplification and analysis were performed using an Applied Bio system with software version 3.1 (StepOne $^{\mathrm{TM}}$, USA) using intron spanning primers with 0 duration controls.

The real time- PCR reaction mixture was $50 \mu 1$ and consisted of $25 \mu 1 \mathrm{SYBR}$ Green Mix (2x), $0.5 \mu$ l kidney cDNA, 2 $\mu l$ primer pair mix $(5 \mathrm{pmol} / \mu \mathrm{l}$ each primer), $22.5 \mu 1 \mathrm{H}_{2} \mathrm{O}$. The used primers' sequences were as follows 


\begin{tabular}{|l|l|}
\hline & Primer sequence \\
\hline LCE2D & $\begin{array}{l}\text { Forward: 5' - TCTGTGCTTTTGCATGTGAC -3' } \\
\text { Reverse: 5'- GGACCACAGCAGGAAGAGAC -3' }\end{array}$ \\
\hline CCL27 & $\begin{array}{l}\text { Forward: 5'-AGCACTGCCTGCTGTACTCA -3' } \\
\text { Reverse: 5'-TTCAGCCCATTTTCCTTAGC -3' }\end{array}$ \\
\hline $\begin{array}{l}\text { Glyceraldehyde } \\
\text { 3-phosphate } \\
\text { dehydrogenase } \\
\text { GAPDH }\end{array}$ & $\begin{array}{l}\text { Forward: 5' CTCCCATTCTTCCACCTTTG-3' } \\
\text { Reverse: 5'- CTTGCTCTCAGTATCCTTGC-3' }\end{array}$ \\
\hline
\end{tabular}

PCR program's set up was; 2 min. at $50^{\circ} \mathrm{C}$ (1cycle), $10 \mathrm{~min}$. at $95^{\circ} \mathrm{C}$ (1cycle), $15 \mathrm{sec}$ at $95^{\circ} \mathrm{C} \rightarrow 30 \mathrm{sec}$ at $60^{\circ} \mathrm{C} \rightarrow 30$ sec at $72^{\circ} \mathrm{C}$ (40 cycles) and $10 \mathrm{~min}$. at $72^{\circ} \mathrm{C}$ (1cycle). The level of expression of each target mRNA was normalized relative to the expression of GAPDH (internal housekeeping gene) in that sample using the $\Delta \mathrm{Ct}$ method. Relative differences in mRNA expression among groups were determined using the comparative $\mathrm{Ct}(\Delta \Delta \mathrm{Ct})$ method.

\section{Statistical methods:}

Data were coded and analyzed using the Statistical Package for Social Sciences (SPSS) version 21. Data was described in terms of mean \pm standard deviation. Comparison of quantitative variables was done using t-test and repeated Measures ANOVA P value less than 0.05 was considered statistically significant.

\section{RESULTS}

Sixty four participants (32males and 32 females) participated in this study. Their mean age was $31.6 \pm 4.6$ years. LCC27and LCE2D mRNA expression levels were $1.026 \pm 0.05$ and $1.127 \pm 0.4$ respectively. Regarding mRNA expression levels, there was no significant difference between the male and female studied groups. Table (1).

Table (1): Gender, age, LCC27 and LCE2D expression among the studied groups

\begin{tabular}{|l|l|l|l|}
\hline Mean \pm SD & Male & Female & P value \\
\hline Age $(31.6 \pm 4.6)$ & $32.80 \pm 4.89$ & $31.00 \pm 4.85$ & 0.420 \\
\hline LCE2D $(1.026 \pm 0.05)$ & $1.02 \pm 0.7$ & $1 \pm 0.5$ & 0.748 \\
\hline LCC27 $(1.127 \pm 0.4)$ & $1.2 \pm 0.4$ & $1 \pm 0.4$ & 0.306 \\
\hline
\end{tabular}

Submerging the samples in water or different $\mathrm{HOCl}$ concentrations decreased LCE2D and LCC27 expressions. Table (2) fig.1. The highest
LCE2D and LCC27 expressions $(0.52 \pm 0.86$ and $0.6 \pm 0.16)$ were found in samples submerged in water.

Table (2): The effects of different concentrations of $\mathrm{HOCl}$ bleach on the expression of LCC27 and LCE2D in the studied samples.

\begin{tabular}{|l|l|l|l|l|}
\hline Mean \pm SD & Air & H2O & Half diluted & Full concentrated \\
\hline LCE2D & $\mathbf{3 1 . 6} \pm 4.6$ & $\mathbf{0 . 5 2} \pm 0.86$ & $\mathbf{0 . 3 2} \pm 0.11$ & $\mathbf{0 . 2 2} \pm 0.12$ \\
\hline LCC27 & $\mathbf{1 . 0 2 6} \pm 0.05$ & $\mathbf{0 . 6} \pm 0.16$ & $0.43 \pm 0.58$ & $\mathbf{0 . 2 6} \pm 0.63$ \\
\hline
\end{tabular}




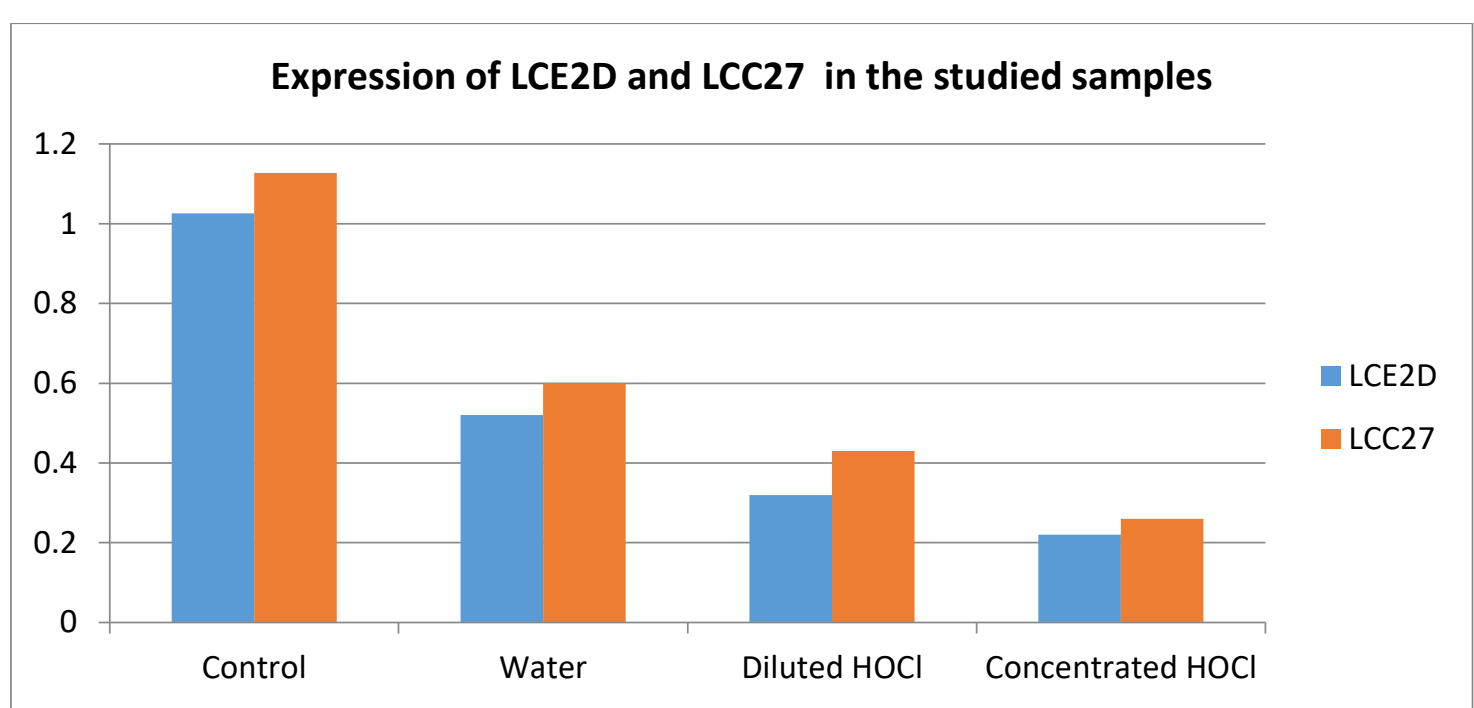

Figure (1): The expression of skin LCE2D and LCC27 marker after using different concentrations of chlorinated bleach.

There was significant difference in LCE2D expression and LCC27 expression in different submerged media $(\mathrm{P}$ value $<0.05)$.

A one-way repeated measured analysis of variances (ANOVA) indicated a significant evidence to accept that the submerged media affected the expression levels of LCE2D (Wilks' Lambda 0.028, F=7.3, $\mathrm{P}<0.05)$ and expression levels of LCC27 (Wilks' Lambda 0.081, $\mathrm{F}=35.9, \mathrm{P}<0.05)$. In close relation, the difference between these pairwise groups $(1,2 / 1,3 / 1,4 / 2,3 / 2,4 / 3,4)$ were significant $(\mathrm{P}$ value $<0.05$ ).

\section{DISCUSSION}

Forensic genetics is an alternative approach for identifying the cellular origin of crime scene's biological stains. Tissue-specific messenger RNA (mRNA) markers are used to detect forensically relevant human body fluids (Visser et al., 2011). Skin-specific mRNA markers, late cornified envelope gene 2D (LCE2D) and chemokine (c-c motif) ligand 27 (CCL27) are considered as highly sensitive and abundant biomarkers (Hanson et al., 2012; Ballantyne, 2013).
Cleaning products can damage the biological samples and make their identification through the currently used forensic analysis procedures difficult (Castelló et al., 2012).

Multiple concentrations of $\mathrm{HOCl}$ solution, were used to remove biological stains like fingerprints from surfaces (Thomasma \& Foran, 2013), were tested to detect the sensitivity of skin mRNA markers to this agent. The present results showed that submerging samples in $\mathrm{HOCl}$ solution, greatly affect the two studied skin mRNA markers; (LCE2D and LCC27). With reducing the concentration of $\mathrm{HOCl}$, the expression of these markers increased and presented in values equal to third of their normal values. Moreover, the pure water affected the studied skin markers. These data declared that soaking the crime scene's biological stains in pure water with or without $\mathrm{HOCl}$ significantly decreased the expression of mRNA skin markers, (LCE2D and LCC27), and making their detection difficult.

Ruissen et al. (1998) found that the keratinocyte gene expression was induced in vitro after application of anionic detergents. These findings were 
due to differentiation switching from the normal one to hyperproliferative/ inflammatory one in the living keratinocyte. They also demonstrated that isolated RNA was degraded due to the detergents' cytotoxicity and they couldn't isolate detectable amount of RNA by northern blots technique. They concluded that detergents' cytotoxicity could be graded according to the amount of isolated intact RNA. Regarding our study $\mathrm{HOCl}$ is considered as moderate cytotoxic detergents.

We were in the same line with a study conducted by Harris et al. (2006), who found that the cleaning agent insignificantly decreased the quality of DNA profiles isolated from washed blood soaked materials.

Wood et al. (1996) stated that the expression of mRNA has been enhanced in skin samples treated with irritant substance.

\section{CONCLUSION}

Expression of skin's markers was reduced after $\mathrm{HOCl}$ treatment. Hence, samples with reduced RNA expressions might be soaked or adulterated before tested, so other tests should be used to help in cellular origin determination before excluding skin source e.g. micro RNA, immune-based assays and DNA methylation (Jennifer \& Fei, 2013).

In our study there was a lack of diversity in the type of substrates tested. However, glass slides were used as an example for smooth non-porous surfaces. More researches using nonporous substrates is needed to detect difference in skin cells attachment and release from them. Qiagen Mini Kit was used to recover RNA. However, this study focused mainly on identifying $\mathrm{HOCl}$ effect on skin-specific RNA markers.

\section{REFERENCES:}

Ballantyne J. (2013): De-convolution of Body Fluid Mixtures: Cell Type Identification and Genetic Profiling of Micro-Dissected Cells. Final report. National Center for Forensic Science. http://www.ncfs.org/.

Castelló A, Francés F, Verdú F. (2012): Chemistry in Crime Investigation: Sodium Percarbonate Effects on Bloodstains Detection. J Forensic Sci. Mar; 57 (2):500-2.

Goray M, Eken E, Mitchell RJ, van Oorschot RA. (2010): Secondary DNA transfer of biological substances under varying test conditions. Forensic Sci. Int. Genet; 4:62-67.

Haas C, Hanson E, Banemann R, Bento AM, Berti A, Carracedo Á et al. (2015): RNA/DNA coanalysis from human skin and contact traces - results of a sixth collaborative EDNAP exercise. Forensic Sci Int Genet. May; 16:139-47.

Hanson E, Hass C, Jucker J, Ballantyne J. (2012): Identification of skin in touch/contact forensic samples by messenger RNA profiling. Forensic Sci Int Genet. Dec; 3(1):e305-e306.

Harris KA, Thacker CR, Ballard D, Syndercombe CD. (2006): The effect of cleaning agents on the DNA analysis of blood stains deposited on different substrates. International Congress Series, April. 1288: 589- 591.

Huang JT, Abrams M, Tlougan B, Rademaker A, Paller AS. (2009): Treatment of Staphylococcus aureus colonization in atopic dermatitis decreases disease severity. Pediatrics. 123(5):e808-e814.

Jackson B, Tilli CM, Hardman MJ, Avilion AA, MacLeod MC, 
Ashcroft GS. (2005): Late cornified envelope family in differentiating epithelia-response to calcium and ultraviolet irradiation. J Invest Dermatol, May; 124(5):1062-70.

Jennifer MR, Fei Y. (2013): Recent Advances in Forensic DNA Analysis. J Forensic Res, Oct. S12: $1-13$.

Lindenbergh A, Maaskant P, Sijen T. (2013): Implementation of RNA profiling in forensic casework. Forensic Sci Int Genet. Jan; 7(1):159-66.

Ruissen VF, Le M, Carroll JM, van der Valk PG, Schalkwijk J. (1998): Differential Effects of Detergents on Keratinocyte Gene Expression. J Invest Dermatol, Apr; 110(4):358-63.

Rutala WA, Cole EC, Thomann CA, Weber DJ. (1998): Stability and bactericidal activity of chlorine solutions. Infect Control Hosp Epidemiol. 19(5):323-327.
Schwark T, Poetsch M, PreussePrange A, Kamphausen T, von Wurmb-Schwark N. (2012): Phantoms in the mortuary--DNA transfer during autopsies. Forensic Sci Int., Mar 10;216(13):121-6.

Thomasma SM, Foran DR. (2013): The Influence of Swabbing Solutions on DNA Recovery from Touch Samples. J Forensic Sci., Mar;58(2):465-9.

Visser M, Zubakov D, Ballantyne KN, Kayser M. (2011): mRNAbased skin identification for forensic applications. Int J Legal Med., Mar;125(2):253-63.

Wood LC, Elias PM, Calhoun C, Tsai JC, Grunfled C, Feingold KR. (1996): Barrier distribution stimulates interleukin-1 alpha expression and release from preformed pool in murine epidermis. J Invest Dermatol 106: 397-403. 
تأثير مادة حمض الهيبوكلوريت علي مستقبلات الحمض النووي الريبوسومي للجلد في عينات الأتصال

سماح فتحي ابراهيم اهب ، مني محمد علي با، سارة عبد المحسن خاطر ع ، ليلي أحمد راشده

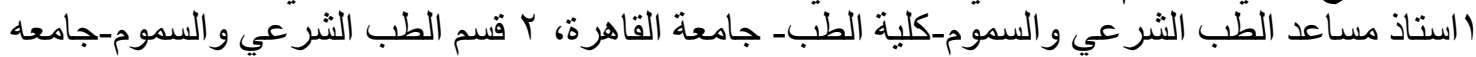

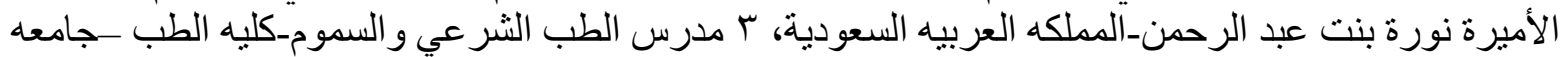

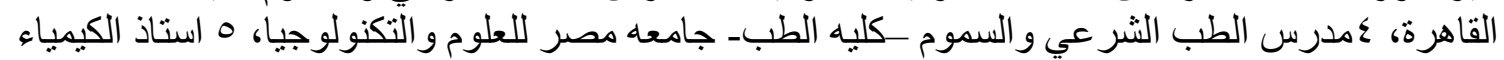
الحيويه_كليه الطب- جامعه القاهرة.

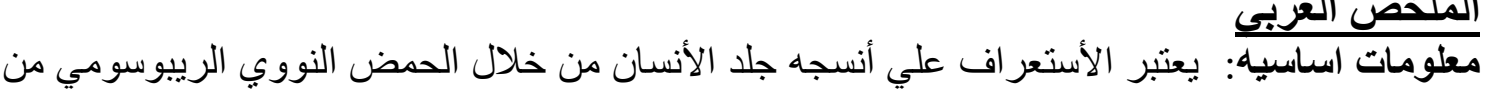

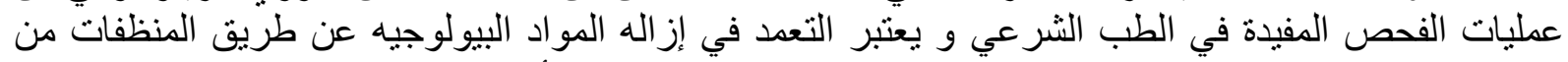

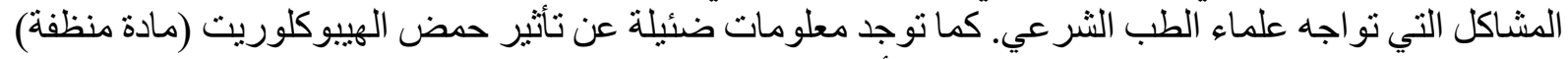

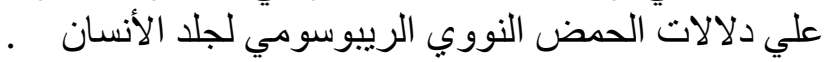

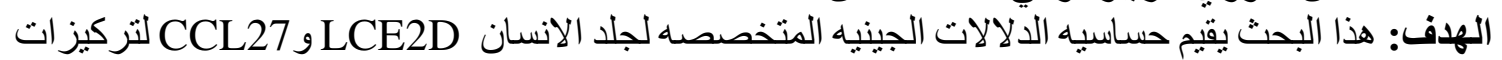

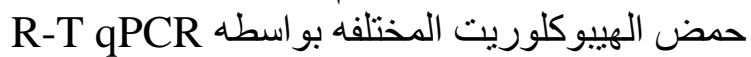
النهج: أربعة وستون متطوع متوسطي العمر وبصحه جيدة من (الذكور بس، r ب الاناث) مضمن في البحث.

النتيجة: وجد أن حمض الهيبوكلوريت له تأثنير سلبي ملحوظ. و وان التعبير الجيني للالالات الجينية تحت

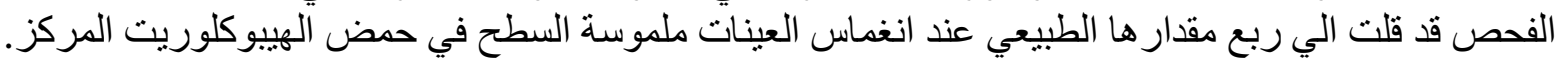

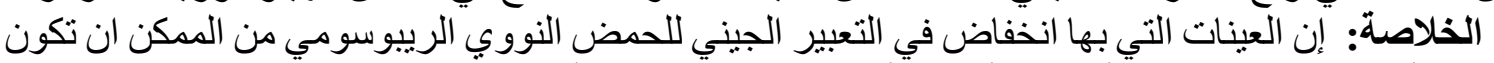

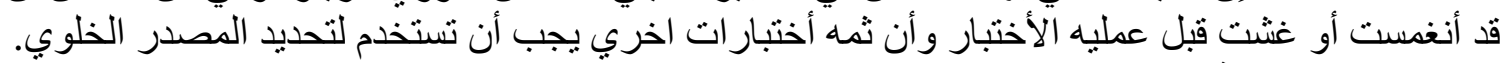

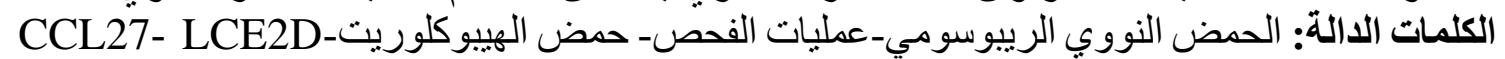
. R-T qPCR- 